\title{
Wildfires and the Dissemination of Information in Oregon
}

\author{
Bruce Wardlow and Alice Perez Ververa
}

Authors' note: This article was originally written on December 10, 2020, and some of the information, specifically about congressional legislation, may be out of date.

Wildfires have the reputation for being fast and unpredictable, government documents tend to be the opposite. So, what happens when the two meet? The 2020 Oregon wildfire season was one of the most destructive in the state's history. We examined the 2020 Oregon wildfires and relief, specifically the Mount Hood fires and witnessed how the world of government publications responded. Wildfires are also very labor-intensive natural disasters to manage in a normal year, and 2020 was even worse. Due to labor constraints of the pandemic, the Oregon 2020 wildfire season was particularly bad. A wide array of federal government organizations quickly got involved, ranging from the IRS to the USDA, as well as state and local agencies. We also learned some specific senators and representatives were quick to respond, although the House and the Senate, as well as the president, were much slower to respond. This is the story of a collection of four distinct fires just outside of Portland, Oregon, that grew to become one large fire control effort, and the governmental responses to this natural disaster. The four wildfires in Oregon we will focus on are the Riverside Fire, Beachie Creek Fire, Lionshead Fire, and P515 Fire.

In the past hundred years, while the scale and devastation of wildfires have grown, the number of casualties from these conflagrations has dropped dramatically, from the thousands in the early 1900s, to less than a hundred in recent years. Much of this has to do with the flow of information, and the active role that the government takes in propagating fire information. In this article we will examine the footprint in the world of government publications that is created by these fire events. Specifically, we will examine the dissemination of information in Oregon in the wake of the 2020 wildfires, using the Riverside Fire, Beachie Creek Fire, Lionshead Fire, and P515 Fire as our representative sample of wildfires.

The response was examined on three different levels: first looking at the federal level, including the responses of various federal agencies, then the president himself, and then at Congress. The state level response was examined next, starting with the various State-level agencies, then the Governor's Office, State Legislature, and ultimately the Oregon State Department of Justice. The final examination was the information response of the local County level.

$\Delta$ unique situation for wildfires in the western states of Oregon, Washington, and California occurred in 2020. In that year's fire season, more than five million acres burned-an area roughly the size of New Jersey. Much of the intensity comes from factors including climate change, forest management, and labor limitations due to the COVID-19 Pandemic. The Riverside Fire, Beachie Creek Fire, Lionshead Fire, and P515 Fire were four fires that were independently ignited; however they grew into a single, concentrated firefighting effort in the Mount Hood National Forest and surrounding area near Portland. 5

The P515, Lionshead, and Beachie Creek fires were ignited on the night of August 16, by a series of lightning strikes. Among the three initial fires the P515 fire grew the fastest. Not long after, however, the Lionshead Fire's spread accelerated until it burned into the P515 Fire. During this time, the Beachie Creek Fire sat, growing very slowly until September 7th, when a straight-line wind event increased the intensity of the flames, causing a rapid spreading of all of the fires in the area. On the same night as the wind event, the Riverside Fire ignited through unspecified human causes. Over the next two weeks the fires grew almost unchecked, with the Beachie Creek Fire burning into the Lionshead Fire. The Riverside Fire was less than a mile from the Beachie Creek Fire when rain events finally stalled out the blaze and allowed mop-up operations to begin. ${ }^{9}$ At the height of the blaze 10 percent of the population of Oregon, upwards of 500,000 people, were either evacuated or under some sort of evacuation warning. Fire operations were projected to cease on October 31 for all fires. ${ }^{8}$ 


\section{Part 1: The Federal Response}

The federal response was well-represented by the executive agencies and the interagency response groups, however the presidential response, as commonly noted by news media, was scarce. Congress also started off very slowly with little evidence of the fires in the Congressional Record, however references to the fires are growing in frequency, and the full response will not be known until after the writing of this article. There were no records of the federal courts being involved in response to the Oregon wildfires from 2020 as of the writing of this article, and given that it may be years before the litigation is resolved, this is to be expected.

\section{Executive Agencies}

The executive agencies, on the other hand, were fastest to provide a singular source of information for the public. They accomplished this through the use of the InciWeb page of the National Wildfire Coordinating Group (NWCG). ${ }^{9}$ The NWCG is an interagency cooperation, originally between the US Department of Agriculture (USDA) and the Department of the Interior, to create a standards organization for wildland fire-

fighting. ${ }^{26}$ It has expanded to include many more agencies, so it is a logical choice to host interagency information. InciWeb performs a minimum of information synthesis, instead operating more like a social media page for wildland fires. It includes news, announcements, maps, photos, and is constantly changing for the life of specific fires. Unfortunately, a fire needs to be considered a large incident to warrant its own InciWeb page. The P-515 and Riverside fires received InciWeb pages within days of their ignition, whereas Lionshead and Beachie Creek, on the other hand, had 20 and 23 days, respectively, between ignition of the fires and the creation of their InciWeb pages. InciWeb linked to multiple different agencies on multiple levels. They included both links to specific information, maps, and press releases, as well as to the public affairs sites of the fires for each of the agencies. Agencies included the United States Department of Agriculture (USDA), the United States Forest Service (USFS), the Bureau of Land Management (BLM), the National Park Service (NPS), the Federal Aviation Administration (FAA), the Federal Emergency Management Agency (FEMA), the Internal Revenue Service, (IRS), the Oregon Department of Transportation, the Oregon Department of Public Health, and the Oregon Department of Environmental Quality, as well as many of the Count Sheriffs' offices, such as Lynn County, Clamack County, and Marion County. Overall, if you knew about InciWeb, or were linked to InciWeb from one of the other associated agencies, there was plenty of up-todate information during the active fire suppression period.

\section{Presidential Response}

The presidential response, while not immediate to the fires themselves, was immediate to the Oregon's Governor's request for aid. On September 10, the president declared a state of emergency for Oregon ${ }^{10}$ at the Governor's request. The Oregon Gubernatorial office issued a press release for a Presidential Disaster Declaration on September 15, the same day as the presidential release. ${ }^{11}$ After that, however, the presidential record stops mentioning the Oregon Wildfires, although many controversial comments are made by the president in regard to the California Wildfires.

\section{Congressional Response}

Congress, in the beginning, was very slow to take any meaningful action in response to the Oregon wildfires. As early as September 16 there were many remarks made thanking and honoring firefighters and first responders, with the Senate even going as far as to passing S.Res.766-A resolution honoring the individuals fighting and the individuals who have fallen responding to wildland fires during the ongoing 2020 wildfire season. ${ }^{12}$ This resolution acknowledged the first responders who participated in the fire suppression effort. Additionally, the resolution honored those who died, but not by name, and the various countries and agencies-they partnered with. This resolution lacks an actionable agenda. These remarks constitute the first six of the fourteen entries in the Congressional Record that mention the Oregon wildfires as of the writing of this article. One exception, however, were some personal remarks from Congressman Peter DeFazio of Oregon, who was absent from Congress for a period due to fires in his district. He commented on what his voting decisions would have been up until Sept. 23, $2020 .^{3}$

The next entries form a sort of transition, where the Oregon and other western wildfires were mentioned in requests for additional time to prepare remarks, ${ }^{30}$ or extensions of remarks. ${ }^{29}$ The first of the actionable bills that saw action directly in response to the fires occurred on November 17, approximately a month after the fires started burning, and about two weeks after the cessation of fire suppression efforts. These were the HOUSING SURVIVORS OF MAJOR DISASTERS ACT OF $2020,{ }^{13}$ the FEMA ASSISTANCE RELIEF ACT OF 2020, ${ }^{14}$ and the RELIABLE EMERGENCY ALERT DISTRIBUTION IMPROVEMENT ACT OF 2020. ${ }^{15}$ Another two bills related to the fires were introduced into Congress, however, these have not appeared on congress.gov as of the writing of this article. 


\section{Part II: State Response}

In comparison with the Federal information response to these wildfires, the State-level response focused on providing people with resources to support in a more general manner. Their primary wildfire information center, the Oregon Wildfire Response \& Recovery website (wildfire.oregon.gov), focused only on current information, and did not differentiate between the fires. The Oregon Governor was outspoken and active on the subject of wildfires; however the-legislature was not. On the other hand, the Oregon Department of Justice produced wildfire-related material.

\section{State Organizational Responses}

The one-stop shop for the state-level organizations is the Oregon Wildfire Response \& Recovery website. Oregon Wildfire Response \& Recovery is an interesting comparison to InciWeb, as InciWeb preserves links and press releases, whereas Oregon Wildfire Response \& Recovery's links are removed without any way to find them again later. When examining the site through the Internet Archive's Wayback Machine for September 15, updated information from September 14 and 15 is available, however when reexamined on December 6, 2020, an entirely different set of links could be found. ${ }^{17}$ In fact, much of the site looks very different, and only some of the links previously available were still there. Additionally, wildfire.oregon.gov does not specify different information for different wildfires, instead serves as a state-wide catch-all for information. Interestingly, I was unable to find any links to the InciWeb page for any of the fires, and the only link to federal agencies were for FEMA. wildfire.oregon.gov links to many other Oregon state agencies, such as the Oregon Department of Transportation, the Oregon Office of Emergency Management, the Oregon Water Resources Department, Business Oregon, the Oregon Department of Forestry, the Oregon Health Authority, and the Oregon Department of Justice, as well as the American Red Cross, and FEMA. ${ }^{16}$

\section{Gubernatorial Response}

The Oregon Governor has been very outspoken about the wildfires. There were 29 press releases from the Governor's Office related to the wildfires, however only a handful were about our "representative" fires, most notably Governor Kate Brown Invokes the Emergency Conflagration Act in Response to Beachie Creek, ${ }^{18}$ Lionshead, and Holiday Farm Fire, Governor Kate Brown Requests Presidential Disaster Declaration for the Ongoing Wildfires in Oregon, ${ }^{19}$ and Governor Kate Brown Visits Clackamas County, Sees Devastation Caused by Wildfires. ${ }^{20}$

\section{State Legislative Response}

The Oregon State Legislature's search tool is problematic, as it does not allow you any ability to sort or filter by date; because of this, the information from Oregon's State Legislature may be incomplete or incorrect. As the Oregon State Legislature is typically in session in the first half of the calendar year, there was no impact in the legislative record from these wildfires at the time this article was written, however there will likely be a significant impact the next time that the State Legislature is in session. There is one misleading entry however, as the Governor's Office released a press release titled Governor Kate Brown Issues Vetoes to Preserve Over \$65 Million for Wildfire Response, Maintain Balanced Budget. ${ }^{21}$ While this is a fire-related entry during the period of our fires, it refers to a HB4304, a bill that was entered and acted upon during the Second Special Session from the period of August 8 through 13, days before the fires started, and does not actually reference these fires. ${ }^{27}$

\section{State Judicial Response}

Interestingly, the Oregon Department of Justice had four articles referencing the wildfires. Three were from the Consumer Protection Division and warned against wildfire-related scams while the fourth was from the Child Support Division providing a point of contact for those whose ability to make or receive child support has been impaired by the loss of home or work as a result of the wildfires. These ranged in date from September 15 to September 28, although two have no announcement dates. $^{22,23}$

\section{Local Level Response}

The local level contained the greatest shift in information sources. While the fires were actively burning, the primary source for fire information was on dedicated sections of the local sheriff's office's websites. ${ }^{24}$ This information focused primarily on road closures, evacuation information, and various ways to contact the local authorities based on your needs. After fire operations ceased the go-to source for information became a dedicated space on the county website. ${ }^{25}$ Unfortunately as neither of these sites identify when new things are added, it is difficult to know when this shift occurred. Much of the information on the county site, however, are links to information at both the state and federal level.

\section{Conclusion}

Today, the Oregon wildfires are still considered an active disaster according to some of the government and federal agencies we've researched. Government publications within the 
state-level are still being updated and wildfire relief deadlines are continuing to be extended. The latest state-level government information regarding the wildfires has to do with a free government-led wildfire debris removal program within the eight counties affected by wildfires. It was also reassuring to find that Oregonians could still get relief from the wildfires and to see how aid has been dispersed to wildfire victims. Some of the dedicated wildfire websites were difficult to navigate, however some public libraries did jump in and gather relief aid information to make it easier for Oregonians to find direct links. ${ }^{28}$ Overall, the most useful resources were from NWCG's InciWeb, as it is the most comprehensive source of wildfire information, while the Governor's Office was also very useful in its transparency and its ease of finding information. Given changing climate conditions, wildfires are only expected to grow in number and intensity, so connecting people with the information that they need is more important than ever.

Bruce Wardlow (wardlowb@uw.edu) and Alice Perez Ververa (alicpere@uw.edu) are students at University of Washington Information School. This paper was written for LIS 526 Government Publications, Fall 2020, Professor Cassandra Hartnett.

\section{Notes}

1. Marion County Oregon, Wildfire Recovery, accessed on December 10, 2020, https:/co.marion.or.us/PW/Emer gencyManagement/Fire/Pages/default.aspx.

2. Oregon Health Authority, Vital Records Fees for Oregonians Affected by the Wildfires under Executive Oregon No. 20-35, September 14, 2020, https:/www.oregon.gov/oha /PH/BIRTHDEATHCERTIFICATES/Documents /OAR333-011-0900TemporaryRules.pdf.

3. Peter A. DeFazio, Personal Explanation, Congressional Record Daily Edition-Extension of Remarks Vol. 166, No. 165, pg. E875, September 23, 2020, https:/www. congress.gov/116/crec/2020/09/23/CREC-2020-09-23pt1-PgE875-3.pdf

4. Donald J. Trump [@realDonaldTrump], September 11, 2020, Tweets [Twitter Profile], https://twitter.com/real donaldtrump/status/1304577591597301760?lang=en.

5. National Wildfire Coordinating Group, Riverside Fire-September 20, 2020 Update, InciWeb, September 20, 2020, https://InciWeb.nwcg.gov/incident/ article/7174/56460/.
6. J. Ramakrishnan and K. Rambo, "Oregon Wildfires: Governor Declares Emergency, Calls Situation 'Dangerous," The Oregonian, September 8, 2020, https://www. oregonlive.com/pacific-northwest-news/2020/09/oregonwildfires-governor-declares-emergency-calls-situationdangerous-live-updates.html.

7. Ted Sickinger, "Oregon's Historic Wildfires: Unusual but Not Unprecedented," The Oregonian, September 15, 2020, https://www.oregonlive.com/news/2020/09/oregons-his toric-wildfires-the-unprecedented-was-predictable.html.

8. B. Schmidt and M. Friesen, "Oregon Initially Said 500,000 Peoplehad been Evacuated because of Wildfires. The Numbers Didn't Add Up-And the State Backtracked," The Oregonian, September 11, 2020, https://www.oregonlive. com/news/2020/09/oregon-said-500000-people-havebeen-evacuated-because-of-wildfires-the-numbers-dontadd-up.html\#:-:text=An\%20online $\% 20$ headline $\% 20$ in $\% 20$ the, as $\% 20$ Fires $\% 20$ Near $\% 20$ Portland $\% 20$ Suburbs.\%E2\%80\%9D.

9. InciWeb, "InciWeb-Incident Information System," accessed December 6, 2020, https://InciWeb.nwcg.gov/.

10. D. Trump, "President Donald J. Trump Approves Oregon Disaster Declaration," Whitehouse.gov, September 10, 2020, https://www.whitehouse.gov/briefings-statements /president-donald-j-trump-approves-oregon-emergency -declaration/.

11. D. Trump, "President Donald J. Trump Approves Oregon Disaster Declaration," Whitehouse.gov, September 15, 2020, https://www.whitehouse.gov/briefings-statements /president-donald-j-trump-approves-oregon-disaster-dec laration-091520/

12. Steve Daines, S.Res.766-A resolution Honoring the Individuals Fighting and the Individuals Who Have Fallen Responding to Wildland Fires during the Ongoing 2020 Wildfire Season, Congressional Bills, October 26, 2020, https://www.congress.gov/congressional-record /2020/10/25/senate-section/article/s6602-2?q=\%7B\%22 search $\% 22 \% 3 \mathrm{~A} \% 5 \mathrm{~B} \% 22$ wildfire+resolution $\% 22 \% 5 \mathrm{D} \%$ 7D\&s $=2 \& \mathrm{r}=2$.

13. Adriano Espaillat, Housing Survivors of Major Disaster Act of 2020, Congressional Bills, May 11, 2020, https:// www.congress.gov/bill/116th-congress/house-bill/2914.

14. Jeff Merkley, S.4627_FEMA Assistance Relief Act of 2020, Congressional Bills, September 17, 2020, https:// www.congress.gov/bill/116th-congress/senate-bill/4627? $\mathrm{q}=\% 7 \mathrm{~B} \% 22 \mathrm{search} \% 22 \% 3 \mathrm{~A} \% 5 \mathrm{~B} \% 22 \mathrm{Fema}+$ Assistance+ Relief + Act + of $+2020 \% 22 \% 5$ D\%7D\&s=5\&r=1. 
15. Jerry McNerney, H.R.6096-READI Act, Congressional Bills, March 5, 2020, https://www.congress.gov/ bill/116th-congress/house-bill/6096?q=\%7B\%22search $\% 22 \% 3 \mathrm{~A} \% 5 \mathrm{~B} \% 22$ Reliable+Emergency+alert+distributi on+act + of $+2020 \% 22 \% 5 \mathrm{D} \% 7 \mathrm{D} \& s=6 \& \mathrm{r}=1$.

16. Wildfire.Oregon.gov, "Oregon Wildfire Recovery," accessed on December 6, 2020, https://wildfire.oregon.gov/.

17. Internet Archive, "wildfire.oregon.gov-Sept. 15, 2020," WayBack Machine, https://web.archive.org/web/20200 915075522/https://wildfire.oregon.gov/.

18. Kate Brown, "Governor Kate Brown Invokes the Emergency Conflagration Act in Response to Beachie Creek, Lionshead, and Holiday Farm Fire," Press Release, September 8, 2020, https://www.oregon.gov/newsroom/Pages /NewsDetail.aspx?newsid=53380.

19. Kate Brown "Governor Kate Brown Requests Presidential Disaster Declaration for the Ongoing Wildfires in Oregon" Press Release, September 14, 2020, https:// www.oregon.gov/newsroom/Pages/NewsDetail.aspx? newsid $=53430$

20. Kate Brown, "Governor Kate Brown Visits Clackamas County, Sees Devastation Caused by Wildfires," Press Release, September 17, 2020, https://www.oregon.gov/news room/Pages/NewsDetail.aspx?newsid $=36673$

21. Kate Brown, "Governor Kate Brown Issues Vetoes to Preserve Over \$65 Million for Wildfire Response, Maintain Balanced Budget," Press Release, September 20, 2020, https://www.oregon.gov/newsroom/Pages/NewsDetail. aspx?newsid $=53476$.

22. Oregon DOJ, "Wildfire Support," Oregon Department of Justice Child Support, September 28, 2020, https://www .doj.state.or.us/child-support/announcements/wildfire-su pport/?hilite $=\% 27$ wildfires $\% 27$.

23. Oregon DOJ, "Five Ways to Avoid Wildfire Donation Scams," Oregon Department of Justice Media, September 15, 2020, https://www.doj.state.or.us/media-home/ news-media-releases/five-ways-to-avoid-wildfire-donation-scams/?hilite $=\% 27$ wildfires $\% 27$.

24. Clackamas County, "Wildfires 2020," accessed December 6, 2020, https://www.clackamas.us/wildfires.

25. Clackamas County Sheriff's Office, "Clackamas County Sheriff's Office," accessed September 21, 2020, https:// www.clackamas.us/sheriff.

26. NWCG, "NWCG Memorandum of Understanding," March 18, 1976, https://www.nwcg.gov/sites/default/files /executive-board/MOU-original-1976.pdf.

27. T. Kotek, HB4304 2020 2nd Special Session-Oregon Legislative Information System, Oregon State Legislature, accessed July 22, 2021, https://olis.oregonlegislature.gov /liz/2020S2/Measures/Overview/HB4304.

28. T. W. Davis, "Wildfire Safety: Resources \& Agencies," Deschutes Public Library, September 11, 2020, https://www .deschuteslibrary.org/about/news/news?newsid=9304.

29. Jimmy Panetta, "SAVE OUR HOMES—SAVE OUR PLANET," Congressional Record, September 16, 2020, https://www.congress.gov/congressional-record/2020 /9/16/house-section/article/h4475-2.

30. Ami Bera, "GRID SECURITY RESEARCH AND DEVELOPMENT ACT," Congressional Record, September 29, 2020, https://www.congress.gov/congress ional-record/2020/9/29/house-section/article/h5025-1. 